\title{
Article \\ Analysis of Growth and Yield of Three Types Cucumbers (Cucumis sativus L.) Based on Yield Components
}

\author{
Kazuya Maeda and Dong-Hyuk Ahn *
}

* Correspondence: ahn@naro.affrc.go.jp

\begin{abstract}
The objectives of this study were to evaluate the yield of different types of cucumbers from the perspective of yield components. The yield and yield components of nine cucumber cultivars (Beit Alpha, Greenhouse, and Japanese) grown hydroponically in a greenhouse were investigated. Fruit yield fresh weight in the Beit Alpha type was higher than that of the Japanese type, and the fruit yield fresh weight was significantly correlated with fruit yield dry weight, total dry matter (TDM), fraction of fruits, and number of fruits. However, the fruit yield fresh weight was not significantly correlated with intercepted light, light use efficiency (LUE), leaf area index, light extinction coefficient, and fruit dry matter content. High fruit yield dry weight was associated with a high TDM and the fraction of fruits. Moreover, the high TDM and fraction of fruits were associated with LUE and the number of fruits, respectively.
\end{abstract}

Keywords: Cucumis sativus L.; fraction of fruits; leaf area index; lowering cultivation; yield component

check for updates

Citation: Maeda, K.; Ahn, D.-H. Analysis of Growth and Yield of Three Types Cucumbers (Cucumis sativus L.) Based on Yield

Components. Horticulturae 2022, 8, 33. https://doi.org/10.3390/

horticulturae 8010033

Academic Editor: Zhihui Cheng

Received: 4 December 2021

Accepted: 27 December 2021

Published: 29 December 2021

Publisher's Note: MDPI stays neutral with regard to jurisdictional claims in published maps and institutional affiliations.

Copyright: (c) 2021 by the authors Licensee MDPI, Basel, Switzerland. This article is an open access article distributed under the terms and conditions of the Creative Commons Attribution (CC BY) license (https:/ / creativecommons.org/licenses/by/ $4.0 /)$.

\section{Introduction}

Cucumbers (Cucumis sativus L.) are among the most widely cultivated vegetable crops worldwide and have many different genotypes [1]. Despite the wide variation in cucumbers worldwide, Japanese cucumbers have relatively narrow diversity [2]. Moreover, Japanese cucumbers have strict standards for fruit size. For example, young cucumbers are approximately $22 \mathrm{~cm}$ in length and $100 \mathrm{~g}$ in weight. Therefore, producing a variety of cucumbers may provide opportunities for market expansion and increased consumption. In yield productivity, Japanese cucumber yield is far lower, at $3.4 \mathrm{~kg} \mathrm{~m}^{-2}$ and $10.7 \mathrm{~kg} \mathrm{~m}^{-2}$ in summer-autumn and winter-spring periods, respectively [3], than in the Netherlands, at $72.8 \mathrm{~kg} \mathrm{~m}^{-2}$ [4]. Moreover, according to data from the Ministry of Agriculture, Forestry and Fisheries, as much as $932 \mathrm{~h}$ of working time are required per $1000 \mathrm{~m}^{-2}$ in summer and autumn cultivation, which is $33 \%$ higher than the $709 \mathrm{~h}$ required for tomato cultivation [5]. Therefore, to increase productivity, it is important to improve the yield while reducing working hours by simplifying operations. Moreover, it is necessary to objectively evaluate the productivity of various types of cucumbers, considering its diversification.

Many investigations have been conducted to compare the characteristics of Japanese and Dutch cultivars to identify the reason for the high yield of Dutch tomato cultivars [6-10]. Moreover, Higashide and Heuvelink [11] analyzed the yield difference of tomatoes developed in different years on the basis of yield components and showed that the yield increase over the past 50 years in Dutch tomatoes resulted from increased total dry matter production, which resulted from high light use efficiency (LUE). In cucumbers, Iwasaki et al. [12] compared one Japanese cultivar to two Dutch cucumbers, based on yield components and reported that the Japanese cultivar had a lower yield than the Dutch cultivar because of lower LUE and the fraction of fruit due to a lower female flowering rate on the main stem. On the other hand, Japanese cucumbers are said to make a difference in yield productivity and the yield productivity depends on the leaf area index (LAI) and female flowering rate $[1,13,14]$. Moreover, cucumber is generally a day neutral crop that induces both male and female 
flowers on the same stem, and the sex expression is affected by environmental factors and genotypes $[15,16]$. These results suggest that the study of variety comparisons in cucumber is insufficient, and more variety comparisons are needed to elucidate the relationship between yield and yield components.

Yield components are a good tool for quantitative yield assessment (Figure 1). Therefore, we cultivated nine cultivars with a hydroponic system for a short period of about four months to evaluate the yield productivity of different types of cucumbers (Beit Alpha type, Greenhouse type, and Japanese type) and analyzed the yield and growth differences based on yield components.

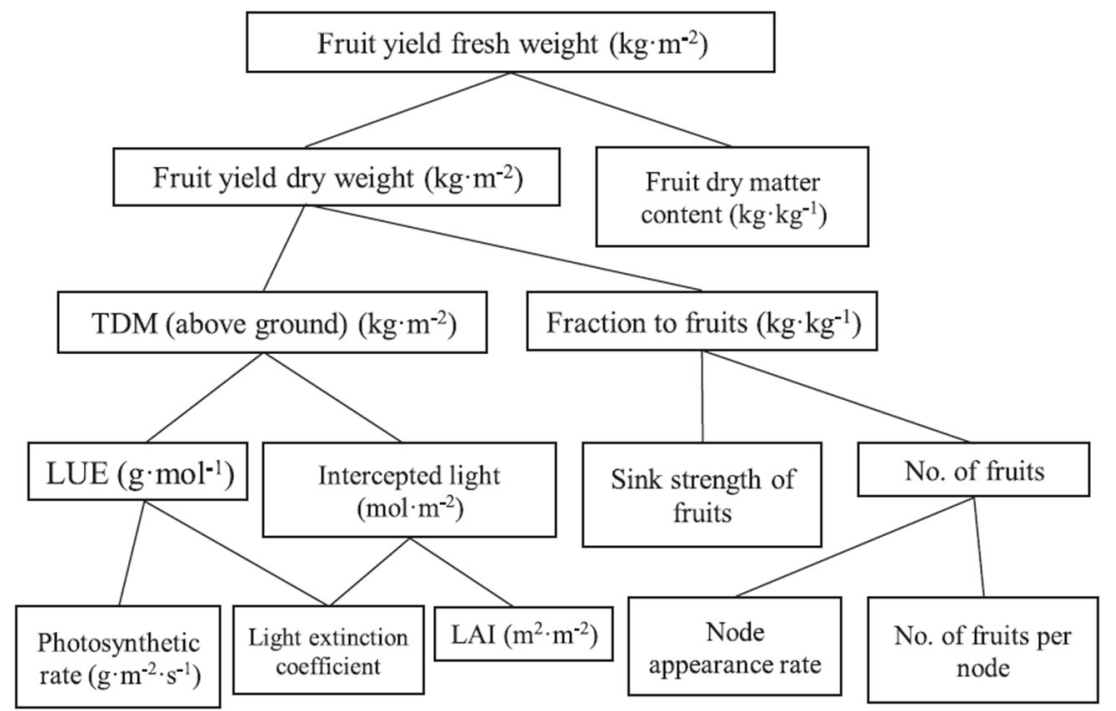

Figure 1. Components contributing to fresh fruit yield in cucumber cited by [17]: total dry matter production (TDM), light use efficiency (LUE), and leaf area index (LAI).

\section{Materials and Methods}

The experiment was conducted in a greenhouse $(27 \mathrm{~m}$ width $\times 36 \mathrm{~m}$ length $\times 3.6 \mathrm{~m}$ height; north-south oriented) covered with polyolefin film. Nine cucumber cultivars were used; 'Media RZ', 'Khasib RZ' (Rijk Zwaan Export B. V, ZUID-HOLLAND, The Netherlands) and 'Atar' (Hazera Genetics Ltd., Berurim M.P Shikmim, Israel) as the Beit Alpha type with short length and large width, without fruit prickles and wart; 'Proloog RZ', 'Marriana RZ' and 'Aviance RZ' (Rijk Zwaan Export B. V, ZUID-HOLLAND, The Netherlands) as the Greenhouse type with long length and medium width, without fruit prickles and wart; 'Eterno' (Tokiwa, Saitama, Japan), 'Fresco 100' (Kurume Vegetable Breeding co., Ltd., Fukuoka, Japan), and 'High-green 21' (Saitama Gensyu Ikuseikai co., Ltd., Saitama, Japan) as the Japanese type with long length and small width, and fruit prickles and wart.

On September 1, the seeds were sown in a cell tray filled with commercial substrate (Na-Terra; Mitsubishi Chemical Agri Dream Co., Ltd., Tokyo, Japan), consisting of vermiculite, peat moss, and red clay soil, and were germinated for a day in a germinator under dark conditions at $28^{\circ} \mathrm{C}$. They were then transferred to a chamber (Nae Terrace; Mitsubishi Chemical Agri Dream Co., Ltd., Tokyo, Japan) set to light and dark periods of $12 \mathrm{~h}$ each at $28{ }^{\circ} \mathrm{C}$ and $20^{\circ} \mathrm{C}$, respectively, with a $\mathrm{CO}_{2}$ concentration of $1000 \mu \mathrm{mol} \mathrm{mol}^{-1}$ and a PPFD of $350 \mu \mathrm{mol} \mathrm{m}{ }^{-2} \mathrm{~s}^{-1}$ for 2 weeks. The seedlings were fertilized every day with commercial nutrient solution (High-Tempo; Sumitomo Chemicals, Tokyo, Japan); the solution consisted of $10.7 \mathrm{me} \cdot \mathrm{L}^{-1} \mathrm{NO}^{3-}, 6.3 \mathrm{me} \cdot \mathrm{L}^{-1} \mathrm{~K}^{+}, 10.8 \mathrm{me} \cdot \mathrm{L}^{-1} \mathrm{Ca}^{2+}, 3.8 \mathrm{me} \cdot \mathrm{L}^{-1} \mathrm{Mg}^{2+}, 7.2 \mathrm{me} \cdot \mathrm{L}^{-1}$ $\mathrm{H}_{2} \mathrm{PO}^{4-}, 3.8 \mathrm{mg} \cdot \mathrm{L}^{-1} \mathrm{Fe}, 0.38 \mathrm{mg} \cdot \mathrm{L}^{-1} \mathrm{Mn}, 0.26 \mathrm{mg} \cdot \mathrm{L}^{-1} \mathrm{~B}, 0.15 \mathrm{mg} \cdot \mathrm{L}^{-1} \mathrm{Zn}, 0.05 \mathrm{mg} \cdot \mathrm{L}^{-1} \mathrm{Cu}$, and $0.07 \mathrm{mg} \cdot \mathrm{L}^{-1} \mathrm{Mo}$, adjusted to an electrical conductivity of $1.8 \mathrm{dS} \cdot \mathrm{m}^{-1}$.

The seedlings were then transplanted into 11 rows (60 plants per row) of rockwool slabs with a 3.09 plants $/ \mathrm{m}^{2}$ plant density, and a high-wire training method (the main-stem of the plant was not pinched, and all lateral branches were removed) was conducted in a 
greenhouse compartment $(21.9 \times 13.5 \mathrm{~m})$. The plants placed at rows 1 and 11 were considered guard plants, and each double row was divided into three blocks (20 plants per block). Each cultivar was arranged over these blocks according to a randomized complete block design with three replicates. The plants were supplied with a commercial nutrient solution (OAT House' fertilizer with modified A prescription; OAT Agrio Co., Ltd., Tokyo, Japan), which consisted of $18.6 \mathrm{me} \cdot \mathrm{L}^{-1} \mathrm{NO}_{3}{ }^{-}, 8.6 \mathrm{me} \cdot \mathrm{L}^{-1} \mathrm{~K}^{+}, 8.2 \mathrm{me} \cdot \mathrm{L}^{-1} \mathrm{Ca}^{2+}, 3.0 \mathrm{me} \cdot \mathrm{L}^{-1}$ $\mathrm{Mg}^{2+}, 5.1 \mathrm{me} \cdot \mathrm{L}^{-1} \mathrm{H}_{2} \mathrm{PO}_{4}{ }^{-}, 2.7 \mathrm{mg} \cdot \mathrm{L}^{-1} \mathrm{Fe}, 1.2 \mathrm{mg} \cdot \mathrm{L}^{-1} \mathrm{Mn}, 0.47 \mathrm{mg} \cdot \mathrm{L}^{-1} \mathrm{~B}, 0.09 \mathrm{mg} \cdot \mathrm{L}^{-1} \mathrm{Zn}$, $0.03 \mathrm{mg} \cdot \mathrm{L}^{-1} \mathrm{Cu}$, and $0.03 \mathrm{mg} \cdot \mathrm{L}^{-1} \mathrm{Mo}$ at an electrical conductivity of $2.6 \mathrm{dS} \cdot \mathrm{m}^{-1}$ by drip irrigation. Three plants for plant growth and fruit yield in the center of the block were measured; thus, nine plants/cultivar were measured. The environment of the greenhouse was controlled using a ubiquitous environmental control system [18]. The temperature settings for the side window ventilation and hot air heater were $28^{\circ} \mathrm{C}$ and $13^{\circ} \mathrm{C}$, respectively.

Destructive measurements (six plants per cultivar) of leaves, stem, fruit fresh weight (FW), dry matter weight (DW), and LAI at 22, 39, and 96 days after transplanting (DAT) were conducted. Nine plants were selected from each cultivar for yield monitoring. To stabilize the initial growth, fruits attached to the 5th node or less from the bottom were removed, and fruits from the 6th node were investigated. The fruits were harvested every day when they reached approximately $100 \mathrm{~g}$. The ratio of fruit DW to fruit FW was defined as the fruit dry matter content (FDMC). The FDMC values in 'Media RZ', 'Proloog RZ', and 'Eterno' $(n=30)$ were measured, and confirmed that there was no difference among the cucumber types (FDMC $=0.03)$. The fraction of fruits was obtained as a value of the total dry weight of the harvested fruits and immature fruits on the plant divided by the total dry matter above ground to the final destructive measurement.

The light extinction coefficient $(k)$ was obtained at 50 DAT using the following equation [19]:

$$
I=I_{0} e^{-k \cdot \mathrm{LAI}}
$$

where $I$ is the photosynthetic photon flux density (PPFD) at a given point in the plant canopy, which was measured using a line quantum sensor (LI-191SA, LI-COR Biosciences, Lincoln, NE, USA) at four different heights within the plant canopy. $I_{0}$ is the PPFD above the canopy, which was measured using a PPFD sensor (LI-190SA, LI-COR Biosciences, Lincoln, NE, USA). LAI is the cumulative LAI at each point from the top.

LUE was defined as the amount of dry matter produced per cumulative intercepted light (IL), using a previously reported method [11]. For some destructive measurements $(0,22,39$, and 96 DAT), the cumulative IL up to the time of destructive measurements was plotted on the horizontal axis, the TDM at that point was plotted on the vertical axis, and the slope of the line was defined as LUE $\left(\mathrm{g} \cdot \mathrm{MJ}^{-1} \mathrm{PAR}\right)$. The daily cumulative photosynthetically active radiation $\left(\mathrm{PAR}, \mathrm{MJ} \cdot \mathrm{m}^{-2}\right)$ for each plant was calculated using the following equation:

$$
\mathrm{IL}=\left(1-e^{-k \cdot \mathrm{LAI}}\right) \times \mathrm{PAR}
$$

PAR is the indoor solar radiation using a facility light transmittance of $50 \%$, which was calculated from the measured outdoor solar radiation by a pyranometer, and recorded every minute. The ratio of the PAR to solar radiation is assumed to be 50\% [20]. The daily LAI was obtained by linearly interpolating the LAI obtained from three destructive measurements.

Results were analyzed using EZR (Saitama Medical Center, Jichi Medical University, Saitama, Japan), which is a graphical user interface for R (The R Foundation for Statistical Computing, Vienna, Austria). All data were analyzed with one-way ANOVA followed by Tukey's multiple comparison and the differences were considered statistically significant at $p<0.05$.

\section{Results}

The environmental data are presented in Figure 2. Cumulative daily outdoor solar radiation showed a decreasing trend with an average value of $9.9 \mathrm{MJ} \cdot \mathrm{m}^{-2}$ during cultivation 
(Figure 2A). The minimum, maximum, and daily average temperatures were 10.0, 34.8, and $20.4{ }^{\circ} \mathrm{C}$, respectively.

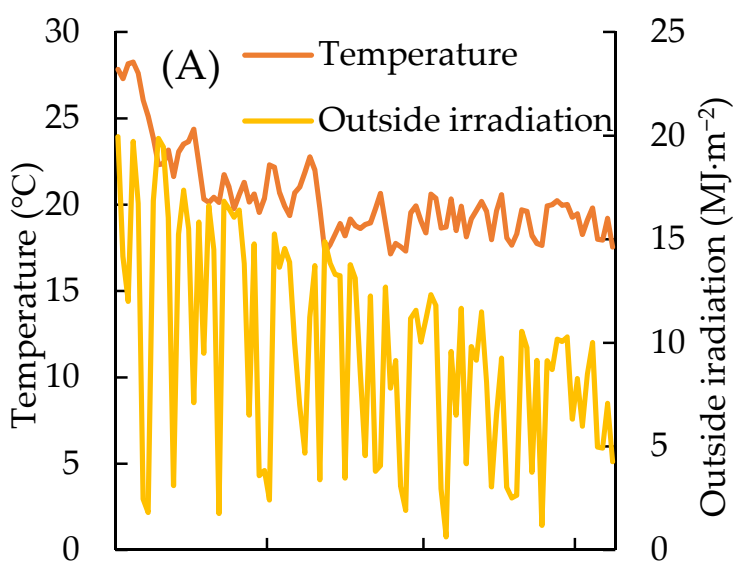

Sep-11 Oct-11 Nov-11 Dec-11

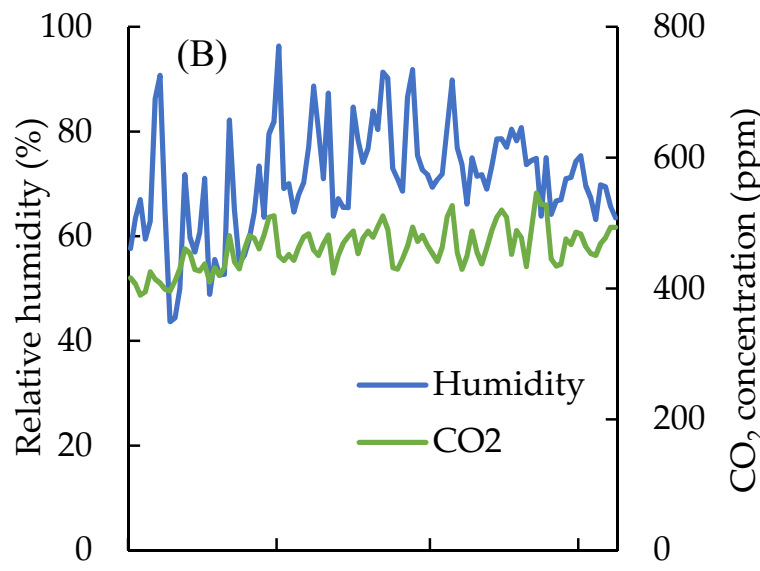

Sep-11 Oct-11 Nov-11 Dec-11

Figure 2. (A) indicates the change in daily mean temperature and outside irradiation, and (B) indicates the daily relative humidity and $\mathrm{CO}_{2}$ concentration.

No significant differences in LAI obtained from the three destructive measurements were observed among the different cultivars (Table 1). The number of fruits and yield FW of 'Khassib RZ' fruits were 54.3 and $14.9 \mathrm{~kg} \cdot \mathrm{m}^{-2}$, respectively, which was the highest among the nine varieties. The average number of fruits per plant were 42.1, 29.5, and 21.7; and average fruit yield FW values were $12.5,10.8$, and $7.8 \mathrm{~kg} \cdot \mathrm{m}^{-2}$ in Beit Alpha, Greenhouse, and Japanese cultivars, respectively. Both the number of fruits and the yield FW of the Beit Alpha type were significantly higher than those of the Japanese type. There were no significant differences in the TDM and DW of leaves among the different cultivars. However, the Beit Alpha cultivars had a higher DW of fruits than the Japanese cultivars. In the fraction of fruits, the average values were $47.2 \%, 43.9 \%$, and $34.1 \%$ in the Beit Alpha, Greenhouse, and Japanese cultivars, respectively. Especially 'Media' and 'Atar' had higher values than Japanese cultivars.

Table 1. LAI, number of fruits per plant, fruit yield fresh weight, leaf, stem and fruit dry weight, total dry matter (TDM), and fraction of fruits of nine cucumbers cultivars at 96 days after transplanting.

\begin{tabular}{|c|c|c|c|c|c|c|c|c|c|}
\hline \multirow{3}{*}{ Type } & \multirow{3}{*}{ Cultivar } & \multirow{3}{*}{$\begin{array}{c}\text { LAI } \\
\mathrm{m}^{2} \mathrm{~m}^{-2}\end{array}$} & \multirow{3}{*}{$\begin{array}{l}\text { No. of Fruits } \\
\text { Per Plant }\end{array}$} & \multirow{2}{*}{$\begin{array}{l}\text { Fruit Yield } \\
\text { Fresh Weight }\end{array}$} & \multicolumn{3}{|c|}{ Dry Weight } & \multirow{2}{*}{ TDM } & \multirow{2}{*}{$\begin{array}{l}\text { Fraction } \\
\text { of Fruit }\end{array}$} \\
\hline & & & & & Leaves & Stem & Fruits & & \\
\hline & & & & $\mathrm{kg} \mathrm{m}^{-2}$ & $\mathrm{~kg} \mathrm{~m}^{-2}$ & $\mathrm{~kg} \mathrm{~m}^{-2}$ & $\mathrm{~kg} \mathrm{~m}^{-2}$ & $\mathrm{~kg} \mathrm{~m}^{-2}$ & $\%$ \\
\hline \multirow[t]{3}{*}{ Beit Alpha } & Media & 3.0 & $38.3 b^{z}$ & $12.3 \mathrm{ab}$ & 0.37 & $0.09 \mathrm{c}$ & $0.44 \mathrm{a}$ & 0.90 & $49.1 \mathrm{a}$ \\
\hline & Khassib & 3.1 & $54.3 \mathrm{a}$ & $14.9 \mathrm{a}$ & 0.45 & $0.11 \mathrm{bc}$ & $0.46 \mathrm{a}$ & 1.02 & $45.1 \mathrm{abc}$ \\
\hline & Atar & 3.1 & $33.7 \mathrm{bc}$ & $10.4 \mathrm{bc}$ & 0.37 & $0.09 \mathrm{c}$ & $0.42 \mathrm{ab}$ & 0.89 & $47.5 \mathrm{a}$ \\
\hline \multirow[t]{3}{*}{ Greenhouse } & Proloog & 3.1 & $30.0 \mathrm{bc}$ & $11.0 \mathrm{bc}$ & 0.36 & $0.12 \mathrm{ab}$ & $0.40 \mathrm{abc}$ & 0.88 & $45.7 \mathrm{ab}$ \\
\hline & Marriana & 3.3 & $27.3 \mathrm{bc}$ & $10.3 \mathrm{~cd}$ & 0.39 & $0.12 \mathrm{ab}$ & $0.37 \mathrm{abcd}$ & 0.88 & $42.5 \mathrm{abc}$ \\
\hline & Aviance & 2.9 & $31.2 \mathrm{bc}$ & $11.0 \mathrm{bc}$ & 0.38 & $0.11 \mathrm{~b}$ & $0.38 \mathrm{abc}$ & 0.87 & $43.6 \mathrm{abc}$ \\
\hline \multirow[t]{3}{*}{ Japanese } & Eterno & 2.7 & $20.1 \mathrm{c}$ & $8.2 \mathrm{~cd}$ & 0.44 & $0.11 \mathrm{~b}$ & $0.29 \mathrm{~cd}$ & 0.84 & $34.9 \mathrm{~cd}$ \\
\hline & Fresco 100 & 2.7 & $26.1 \mathrm{bc}$ & $8.3 \mathrm{~cd}$ & 0.41 & $0.12 \mathrm{ab}$ & $0.30 \mathrm{bcd}$ & 0.83 & $36.6 \mathrm{bcd}$ \\
\hline & Highgreen 21 & 3.1 & $19.0 \mathrm{c}$ & $6.9 \mathrm{~d}$ & 0.45 & $0.13 \mathrm{a}$ & $0.26 \mathrm{~d}$ & 0.85 & $30.8 \mathrm{~d}$ \\
\hline
\end{tabular}

${ }^{\mathrm{z}}$ Different letters indicate significant differences at $p<0.05$ by ANOVA followed Tukey's multiple comparison test $(n=9)$.

Figure 3 shows the changes in the cumulative fruit yield FW of each cultivar from October 10th to December 21st. Looking at the changes in cumulative fruit yield FW, the Beit Alpha type cultivars started harvesting earlier than the other cultivars. While the yield of 'Khassib RZ' increased constantly from the start of harvest to the end of the experiment, the three Japanese cultivars started harvesting later than the other cultivars and the rate of yield increase was sluggish. 


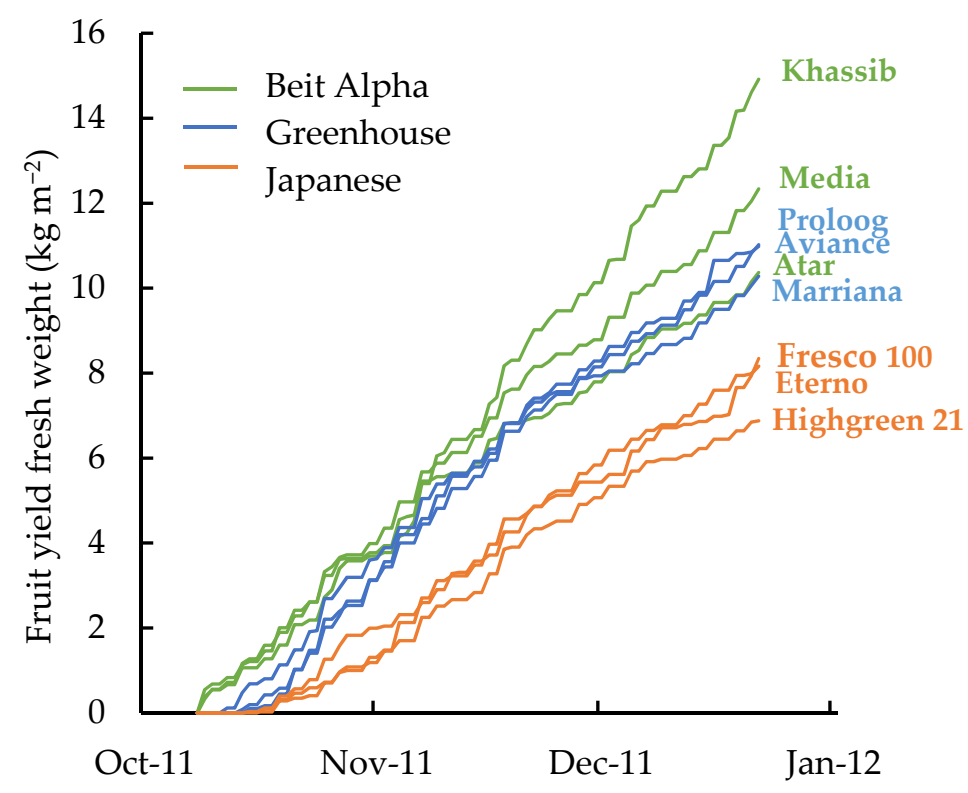

Figure 3. Cumulative fruit yield fresh weight in nine cucumber cultivars.

The light extinction coefficient measured at 50 DAT, based on 95\% confidence intervals, and no significant difference was observed among the different cultivars (Figure 4). The values were $0.80,0.99,0.90,0.97,0.90,0.79,0.93,0.77$ and 1.01 in 'Media RZ', 'Khasib RZ', 'Atar', 'Proloog RZ', 'Marriana RZ' , 'Aviance RZ', 'Eterno', 'Fresco 100' and 'High-green', respectively. $\left(\mathrm{R}^{2}=0.93-0.98, p<0.01\right)$. The average values of light extinction coefficient were 0.90, 0.89, and 0.90 in the Beit Alpha, Greenhouse, and Japanese cultivars, respectively.
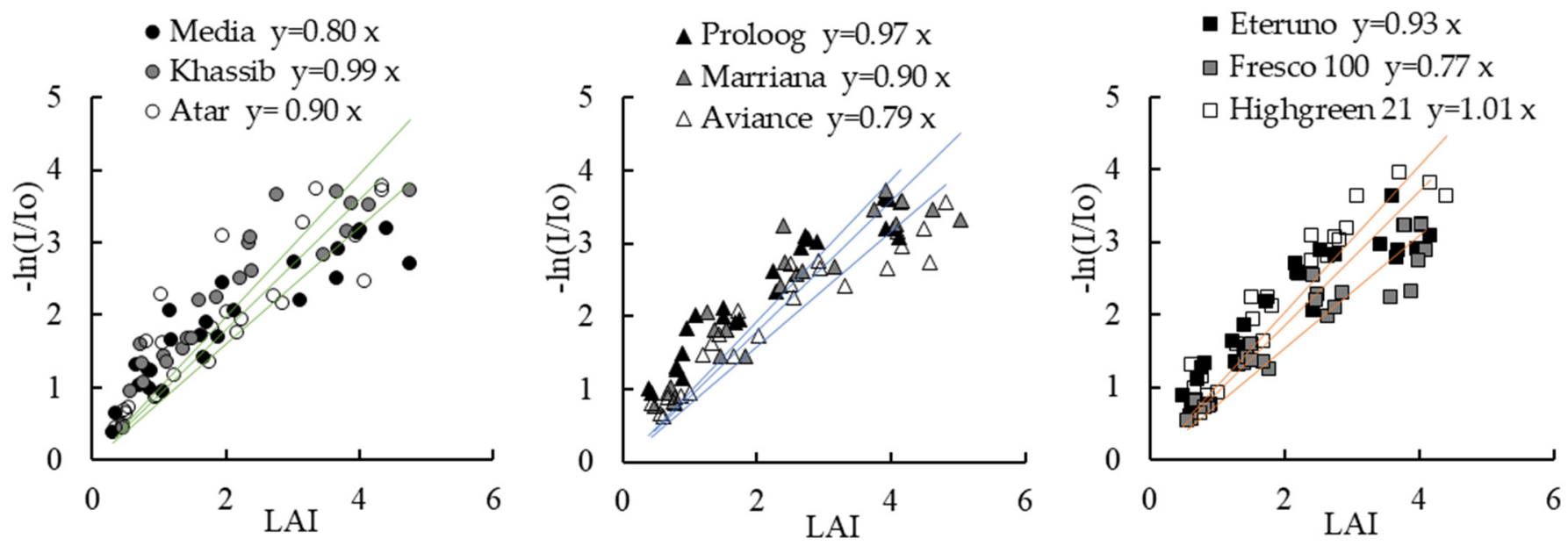

Figure 4. Extinction coefficient (k) in the nine cucumber cultivars.

Figure 5 shows the relationship between cumulative IL and TDM in the nine cucumber cultivars. The average cumulative IL at 22, 39, and 96 DAT, calculated by Equation (2), were $33.4,74.9$, and $187.9 \mathrm{MJ} \cdot \mathrm{m}^{-2}$ in the Beit Alpha cultivars, $32.5,73.9$, and $186.6 \mathrm{MJ} \cdot \mathrm{m}^{-2}$ in the Greenhouse cultivars, and $26.9,66.6$, and $178.9 \mathrm{MJ} \cdot \mathrm{m}^{-2}$ in the Japanese cultivars (Figure 5). The values were 4.6, 4.9, 4.2, 4.2, 4.4, 4.6, 4.4, 4.6 and 4.2 in 'Media RZ', 'Khasib RZ', 'Atar', 'Proloog RZ', 'Marriana RZ', 'Aviance RZ', 'Eterno', 'Fresco 100' and 'High-green', respectively $\left(\mathrm{g} \cdot \mathrm{MJ}^{-1}\right.$, MJ is a unit of photosynthetically active radiation), $\left(\mathrm{R}^{2}=0.97-0.99\right.$, $p<0.01$ ). Based on $95 \%$ confidence intervals, no significant difference was observed among the different cultivars for LUE, which is the slope of the regression line between IL and TDM. 


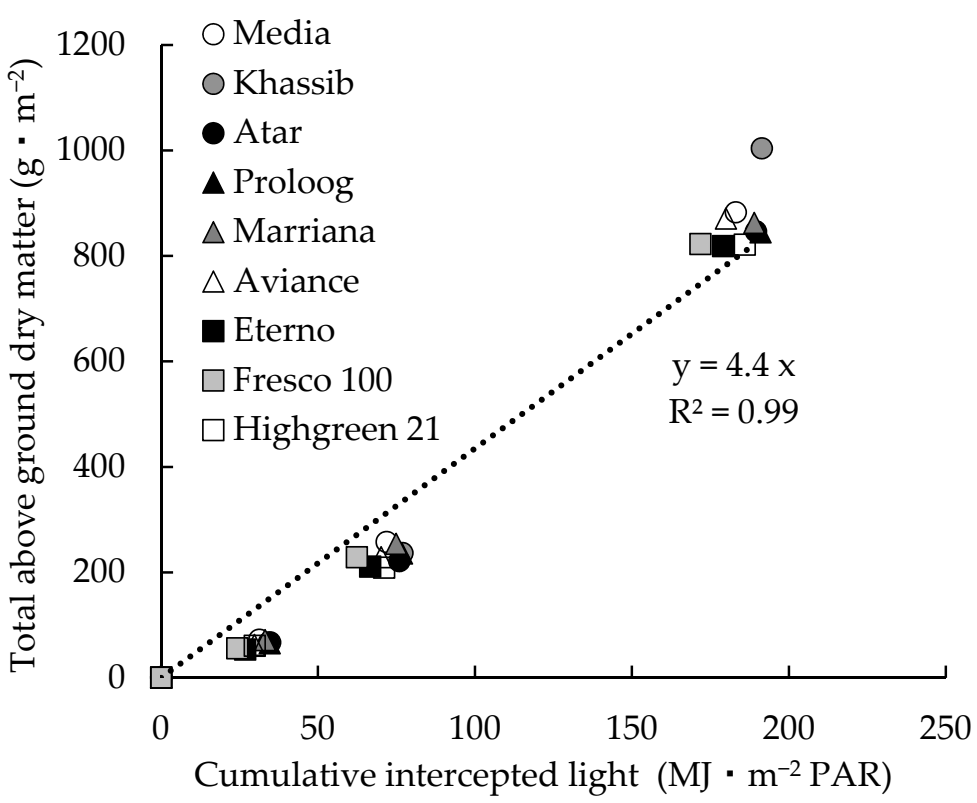

Figure 5. Total above-ground dry matter as a function of cumulative intercepted PAR in the nine cucumber cultivars. The slopes of the regression lines are light use efficiency.

Correlations among the yield components are shown in Table 2. Fruit yield FW was significantly positively correlated with fruit yield DW, TDM, the fraction of fruits, and the number of fruits. The factor with the highest correlation coefficient with fruit yield FW was fruit yield DW, followed by the fruit fraction, number of fruits, and TDM. Moreover, fruit yield DW was significantly positively correlated with TDM, the fraction of fruits, and the number of fruits. However, no significant correlation was found with LUE, IL, the extinction coefficient, LAI, or the light extinction coefficient for either fruit yield FW or DW. Additionally, there was a significant positive correlation between TDM and LUE, the fraction of fruits, and the number of fruits.

Table 2. Correlation coefficient (r) between yield components and growth characteristics of cucumber cultivars at 96 days after transplanting.

\begin{tabular}{|c|c|c|c|c|c|c|c|c|}
\hline & $\begin{array}{l}\text { Fruit Yield } \\
\text { Dry Weight }\end{array}$ & $\begin{array}{l}\text { Total Dry } \\
\text { Matter }\end{array}$ & $\begin{array}{l}\text { Fraction } \\
\text { of Fruits }\end{array}$ & $\begin{array}{l}\text { Light Use } \\
\text { Efficiency }\end{array}$ & $\begin{array}{l}\text { Intercepted } \\
\text { Light }\end{array}$ & $\begin{array}{l}\text { Leaf Area } \\
\text { Index }\end{array}$ & $\begin{array}{l}\text { Light Extinction } \\
\text { Coefficient }\end{array}$ & $\begin{array}{c}\text { Number of } \\
\text { Fruits }\end{array}$ \\
\hline Fruit yield fresh weight & 0.98 & 0.80 & 0.91 & 0.58 & 0.46 & 0.30 & -0.09 & 0.91 \\
\hline Significance & $* * * \mathrm{z}$ & $* *$ & $* * *$ & NS & NS & NS & NS & $* * *$ \\
\hline Fruit yield dry weight & & 0.88 & 0.85 & 0.64 & 0.49 & 0.34 & -0.03 & 0.96 \\
\hline Significance & & $* *$ & $* *$ & NS & NS & NS & NS & $* * *$ \\
\hline Total dry matter & & & 0.54 & 0.68 & 0.60 & 0.41 & 0.33 & 0.94 \\
\hline Significance & & & NS & $*$ & NS & NS & NS & $* * *$ \\
\hline Fraction to fruits & & & & & & & & 0.70 \\
\hline Significance & & & & & & & & $*$ \\
\hline
\end{tabular}

$\mathrm{z} * * * * *$, and $*$ indicate significant correlation at $p<0.001, p<0.01$, and $p<0.05$, respectively. NS indicates not significant difference.

\section{Discussion}

The yield components have a hierarchical structure, and the elements of the lower layer determine the elements of the upper layer in tomatoes [11]. This is also applicable to cucumber [12,17], where fruit fresh yield is determined by FDMC and fruit dry matter yield, which in turn is determined by TDM and the fraction of fruits. The TDM is determined by the LUE and cumulative IL, and the LUE is determined by the photosynthetic rate of individual leaves and the light extinction coefficient. In this experiment, the yield of the Beit Alpha cultivars was higher than that of the Japanese cultivars. Therefore, we discuss the cause of this difference in terms of the yield components. 
There was no correlation between fruit yield fresh weight and FDMC, suggesting that fruit yield fresh weight was not affected by FDMC (data not shown). This is supported by the fact that there was no significant difference in FDMC among the cultivars. Furthermore, there was a significant correlation between fruit yield fresh weight and fruit yield dry weight (Table 2), indicating that higher fresh weight was associated with higher fruit dry weight. Moreover, fruit yield dry weight was significantly positively correlated with TDM and the fraction of fruits. Therefore, the higher yield of fruit dry weight in the Beit Alpha cultivars than in Japanese cultivars might be attributed to both higher TDM and the higher fraction of fruits. However, there were no significant differences in TDM among the different cultivars in this study, indicating that a higher fraction of fruits was the main factor causing the yield difference. Moreover, the fraction of fruits was associated with the number of fruits. In this study, the fraction of fruits was $31-37 \%$ in Japanese cultivars, which was lower than $48 \%$ [12] and 70-72\% [17] that was reported in previous studies. This result might be due to the lower female flowering rate, especially in the early stages of harvest. The female flowering rate in cucumbers is mainly affected by temperature and photoperiod $[15,21,22]$. In this study, the plants were transplanted during the summer season, and the daily average temperature was above $25^{\circ} \mathrm{C}$. Therefore, integration of higher temperatures and longer photoperiod might have decreased the female flowering rate in Japanese cultivars and thus decreased the fraction of fruits and yield.

In conclusion, Beit Alpha cultivars had higher fruit yield fresh weights than Japanese cultivars. The high fruit yield fresh weight was due to a high fruit yield dry weight, and the dry weight was associated with TDM and fraction of fruits. The reason for the lower female flowering rate was consistent with that of a previous study on the lower yield of Japanese cultivars than that of Dutch cultivars [12] and the low female flowering rate on the main stem of Japanese cultivars is thought to be due to the breeding objectives of Japanese cucumber. Pinching cultivation is commonly preferred in cucumber production in Japan, where cultivars have been bred with high female flowering rates on side branches. However, lowering cultivation methods have attracted attention for simplifying work in terms of training method [23,24]. Therefore, in the future, it will be important to breed cultivars with high female flowering rates on the main branch.

\begin{abstract}
Author Contributions: Conceptualization, K.M. and D.-H.A.; methodology, K.M. and D.-H.A.; software, K.M. and D.-H.A.; validation, K.M. and D.-H.A.; formal analysis, K.M.; investigation, K.M. and D.-H.A.; resources, K.M. and D.-H.A.; data curation, K.M. and D.-H.A.; writing-original draft preparation, K.M. and D.-H.A.; writing—review and editing, K.M. and D.-H.A.; visualization, K.M. and D.-H.A.; supervision, K.M. and D.-H.A. All authors have read and agreed to the published version of the manuscript.
\end{abstract}

Funding: This research received no external funding.

Institutional Review Board Statement: Not applicable.

Informed Consent Statement: Not applicable.

Data Availability Statement: Not applicable.

Conflicts of Interest: We (Kazuya Maeda and Dong-Hyuk Ahn) declare that there is no conflict of interest as far as our work is concerned.

\title{
References
}

1. Sakata, Y.; Sugiyama, M.; Yoshioka, Y.; Ohara, T. Morphological Characteristics and Yield of Five Major Cucumber Types under Cultivation in Japan. Bull. Natl. Inst. Veg. Tea Sci. 2010, 9, 113-123.

2. Sakata, Y.; Sugiyama, M. Characteristics of Japanese Cucurbits. Acta Hortic. 2002, 588, 195-203. [CrossRef]

3. MAFF. 2020. Available online: https://www.maff.go.jp/j/tokei/kouhyou/sakumotu/sakkyou_yasai/ (accessed on 1 September 2021).

4. FAOSTAT. 2018. Available online: http://faostat.fao.org/site/ (accessed on 5 September 2021).

5. MAFF. e-Stat. 2010. Available online: https://www.maff.go.jp/j/tokei/kouhyou/engei/ (accessed on 5 September 2021).

6. Matsuda, R.; Suzuki, K.; Nakano, A.; Higashide, T.; Takaichi, M. Response of Leaf Photosynthesis and Plant Growth to Altered Source Sink Balance in Japanese and Dutch Tomato Cultivar. Sci. Hortic. 2011, 127, 520-527. [CrossRef] 
7. Matsuda, R.; Nakano, A.; Ahn, D.; Suzuki, K.; Yasuba, K.; Takaichi, M. Growth Characteristic and Sink Strength of Fruit at Different CO2 Concentrations in a Japanese and Dutch Tomato Cultivars. Sci. Hortic. 2011, 127, 528-534. [CrossRef]

8. Matsuda, R.; Ahn, D.; Nakano, A.; Suzuki, K.; Takaichi, M. Leaf Gas Exchange Characteristics of Four Japanese and Four Dutch Tomato Cultivars Grown in a Greenhouse. Sci. Hortic. 2013, 156, 19-23. [CrossRef]

9. Maeda, K.; Johkan, M.; Tsukagoshi, S.; Maruo, T. Effect of Salinity on Photosynthesis and Distribution of Photosynthates in the Japanese Tomato 'CF Momotaro York' and the Dutch Tomato 'Endeavour' with Low Node-Order Pinching and a High-Density Planting System. Hort. J. 2020, 89, 454-459. [CrossRef]

10. Maeda, K.; Johkan, M.; Tsukagoshi, S.; Maruo, T. Differences of Morphological Characteristics between Japanese Tomato ‘CF Momotaro York' and Dutch Tomato 'Endeavour' with Single-Truss Tomato Plants Grown at High Density. Environ. Control Biol. 2020, 58, 59-63. [CrossRef]

11. Higashide, T.; Heuvelink, E. Physiological and Morphological Changes over the Past 50 Years in Yield Components in Tomato. J. Amer. Soc. Hort. Sci. 2009, 134, 460-465. [CrossRef]

12. Iwasaki, Y.; Ahn, D.; Shimomura, K.; Higashide, T.; Nakano, A. Optimizing Training Method and Environmental Factors to Improve the Growth and Yield of Cucumbers. Bull. Natl. Inst. Veg. Tea Sci. 2014, 13, 65-73.

13. Asao, T.; Umeyama, M.; Ohta, K.; Hosoki, T.; Ito, N.; Ueda, H. Decrease of Yield of Cucumber by Non-Renewal of the Nutrient Solution and Its Reversal by Supplementation of Activated Charcoal. J. Jpn. Soc. Hortic. Sci. 1998, 67, 99-105. [CrossRef]

14. Sato, T.; Takiguchi, T.; Matsuura, K.; Narimatsu, J.; Mizuno, N. Effects of High Temperature Caused by Non-Ventilation of Greenhouse on the Growth and Prevention of Disease and Insect Damage in Summer-Grown Cucumber. Engei Gakkai Zasshi 2003, 72, 56-63. [CrossRef]

15. Lai, Y.S.; Shen, D.; Zhang, W.; Zhang, X.; Qiu, Y.; Wang, H.; Dou, X.; Li, S.; Wu, Y.; Song, J.; et al. Temperature and Photoperiod Changes Affect Cucumber Sex Expression by Different Epigenetic Regulations. B.M.C. Plant Biol. 2018, 18, 268.

16. Jat, G.S.; Munshi, A.D.; Behera, T.K.; Choudhary, H.; Dash, P.; Ravindran, A.; Kumari, S. Genetics and Molecular Mapping of Gynoecious (F) Locus in Cucumber (Cucumis sativus L.). J. Hortic. Sci. Biotechnol. 2019, 94, 24-32. [CrossRef]

17. Higashide, T.; Gotoh, I.; Suzuki, K.; Yasuba, K.; Tsukazawa, K.; Ahn, D.; Iwasaki, Y. Effects of Pinching and Lowering on Cucumber Yield and Yield Components. J. Jpn. Soc. Hortic. 2012, 11, 523-529.

18. Yasuba, K.; Kurosaki, H.; Takaichi, M.; Suzuki, K. Development of a Management Software for Protected Horticulture Based on the Practical Protocol of Ubiquitous Environment Control System. Bull. Natl. Inst. Veg. Tea Sci. 2012, 11, 63-72.

19. Monsi, M. Über den Lichtfaktor in den Pflanzengesellschaften und seine Bedeutung für die Stoffproduction. Jpn. J. Bot. 1953, 14, 22-52.

20. Ohtani, Y. Effective Radiation, Micrometeorological Phenomena. In Agricultural Meteorology Glossary; Maki, T., Iwata, S., Uchijima, Z., Oikawa, T., Omasa, K., Kurata, K., Kozai, T., Goto, E., Kon, E.H., Nouchi, I., et al., Eds.; Society for Agricultural Meteorology of Japan: Tokyo, Japan, 1997; pp. 106-107. (In Japanese)

21. Ito, H.; Saito, T. Factors Responsible for the Sex Expression of Japanese Cucumber.VI. J. Jpn. Soc. Hortic. 1957, 26, 1-8. [CrossRef]

22. Hikosaka, S.; Boonkorkaew, P.; Sugiyama, N. Effects of Air Temperature at the Seedling Stage and Pollination on the Development of Pistillate Flowers and Fruit Set in Cucumbers. Environ. Control Biol. 2008, 46, 249-256. [CrossRef]

23. Isomura, M.; Matsugaki, Y.; Funakoshi, Y.; Tokumaru, K.; Tanaka, K.; Araki, Y. Techniques for High Yield and Quality in Cucumbers Cultured in Greenhouses by Vertical Training. Bull. Oita Prefect. Agric. Res. Cent. 2001, 31, 31-39.

24. Ota, T.; Seino, H.; Inoue, N. New Method of Training for Cucumber in Greenhouse. Bull. Saitama Prefect. Agric. For. Res. Cent. 2005, 4, 79-83. 